1 ま えがき

腐食損傷は，今日では社会活動全般に係わる問題で あり，腐食によりこうむる被害は，単に経済的損失， 資源エネルギの損失にとどまらず，環境污染，ひいて は人的被害にまで至ることがある。そのため，腐食損 傷に関する研究の推進が要望されるとともに, 腐食損 傷の実態を知り，その対策と設計・保全のための資料 の公表が望まれている.

日本材料学会腐食防食部門委員会では，その部門を (1)金属材料，(2)非金属材料，(3)防食設計 - 防食管理,

(4)事故調査・対策，(5)腐食防食試験法の五つの主題に 分けて運営する方式をとっている．この中で事故調查 および対策の問題はとくに，例会発表のみに終ること なく，腐食防食試験法および防食設計・防食管理と関 連させながら，その情報を恒久的に蓄積整理して行く ことが必要であり，このことを目的として1975年11月 ，Task Group「腐食事例」（TG と略記）を編成した. TG では最初の作業として, 応力腐食割れ (SCC) 事 例の収集と解析を行らこととし，1977年11月までの間 に15回の会合がもたれ，一応の作業が終了した，その 作業の集大成は昭和 53 年 1 月「応力腐食割的事例の収 集と解析」として日本材料学会腐食防食部門委員会よ り発行され，幸いにも好評を博している.

\section{$2 \mathrm{SCC}$ 事例の帅集}

広範多岐にわたる腐食現象の中で，かって最も頻発 した全面腐食は孔食とともに年ごとに減少しているの に対し, SCCの比率が次第に増加していること, SCC については従来より多くの研究成果が発表され，技術 的関心度も高いことを考光，SCC 事例の収集之解析 をまず取り上げることにしたものである，広義のSCC の範ちゅらに入る水素ぜい化割れ，液体金属ぜい化と， 腐食疲労事例についても可能な限りあわせて収集する こととした。

TG の最初の作業は腐食事例收集カードの作製より 始まった。腐食防食部門委員会で腐食表示に関する小 委員会を設置し，腐食事故調查表を作製した際の経験 を踏まえまず収集カードのアウトラインを次のよう に定めた。

* 原稿受理 昭和54年 4 月 10 日

** 正会 員 京都大学工学部 京都市左京区吉田本町
（1）主要な腐食現象ごとに専用の収集カードを作製 する。

（2）カードは 1 件 1 葉とする.

（3）項目をできるだけ整理し，記載の便を考兄る.

（4）収集された事例を分類整理する際の便を考学る。 収集カードはSCC 以外に高温腐食事例収集カード, 水素侵害事例收集カードも作成し, 以後の作業に備え た. SCC 事例收集カードは表 Iに示すよらな欄に分 かれ, カード右欄外には, 材料, 環境, 温度範囲, 割

表 I SCC 事例收集カード記載欄記入状況

\begin{tabular}{|c|c|c|c|c|c|}
\hline & 記 載 項 & 目 & $\begin{array}{l}\text { 外 国 } \\
\text { 文 献 }\end{array}$ & 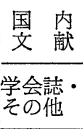 & 合 計 \\
\hline 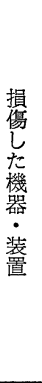 & 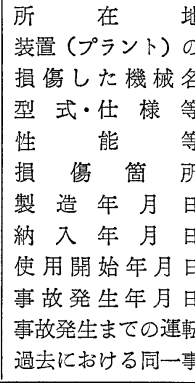 & $\begin{array}{l}\text { (工場名) } \\
\text { 多称 } \\
\\
\text { (推 定) } \\
\text { 使用)延時間 } \\
\text { 溌生頻度 }\end{array}$ & $\begin{array}{r}6 \\
45 \\
56 \\
8 \\
8 \\
3 \\
61 \\
1 \\
0 \\
2 \\
2 \\
40 \\
10\end{array}$ & $\begin{array}{r}49 \\
127 \\
142 \\
9 \\
7 \\
133 \\
2 \\
0 \\
16 \\
20 \\
116 \\
6\end{array}$ & $\begin{array}{r}55 \\
172 \\
198 \\
17 \\
10 \\
194 \\
3 \\
0 \\
18 \\
22 \\
156 \\
16\end{array}$ \\
\hline & 傷 & 態 & 63 & 129 & 192 \\
\hline $\begin{array}{l}\text { 構 } \\
\text { 成 } \\
\text { 材 } \\
\text { 料 }\end{array}$ & 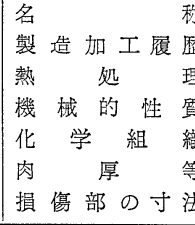 & （規 格） & $\begin{array}{r}71 \\
25 \\
17 \\
19 \\
7 \\
30 \\
11\end{array}$ & $\begin{array}{r}165 \\
10 \\
16 \\
16 \\
14 \\
66 \\
10\end{array}$ & $\begin{array}{r}236 \\
35 \\
33 \\
35 \\
21 \\
96 \\
21\end{array}$ \\
\hline \multirow{3}{*}{$\begin{array}{l}\text { 腐 } \\
\text { 食 }\end{array}$} & \multicolumn{2}{|l|}{ 主環境の組成・濃度 } & 57 & 144 & 201 \\
\hline & 温度と測定場所 & \begin{tabular}{|ll} 
平 & 均 \\
最 & 高 \\
最 & 低
\end{tabular} & $\begin{array}{r}11 \\
6 \\
7\end{array}$ & $\begin{array}{l}61 \\
49 \\
39\end{array}$ & $\begin{array}{l}72 \\
55 \\
46\end{array}$ \\
\hline & $\mathrm{C}^{-}$濃 度 & $\begin{array}{lll}\text { 液 本 体 } \\
\text { 損 傷 部 }\end{array}$ & $\begin{array}{l}1 \\
1\end{array}$ & $\begin{array}{l}40 \\
19\end{array}$ & $\begin{array}{l}41 \\
20\end{array}$ \\
\hline 境 & 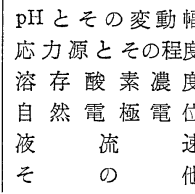 & （腐食電位） & $\begin{array}{r}3 \\
36 \\
0 \\
0 \\
0 \\
1\end{array}$ & $\begin{array}{r}27 \\
50 \\
3 \\
0 \\
2 \\
7\end{array}$ & $\begin{array}{r}30 \\
86 \\
3 \\
0 \\
2 \\
8\end{array}$ \\
\hline & 因と & 策 & 60 & 119 & 179 \\
\hline & & 記 & 33 & 73 & 106 \\
\hline
\end{tabular}


れの分類の 4 項目のインデックスを合わせて記載した ものである.

SCC事例収集の対象は腐食防食部門委員会関係資料, 他学協会関係資料 (151種), 社内事例であり, これら を各委員の分担により調査の結果, 243 例の詳細な SCC 事例カードが集録された. SCC 事例を記載した 文献は外国誌 12 種，国内誌 21 種であり，国内誌の主な ものは, 腐食防食部門委員会関係資料 (30 例), 石油 学会資料 (30 例), ステンレス（28 例）である. 外国 誌からの收録は69例で, ASM Metals Handbook (40 例), Chemical Engng. Progress（9 例）などが主な るのである.

これらの事例報告に括いて収集カードの記載欄にど の程度記入がなされていたかについての調査結果を表 Iに示す、損傷した機器・装置名, 損旐個所, 運転延 時間, 構成材料, 主環境の組成・濃度, 原因之対策に ついての記入率が極めて高い一方, 環境の温度, $\mathrm{Cl}^{-}$, $\mathrm{pH}$ とその変動幅, 溶存酸素濃度や応力源とその程度 汇関する記入が少いことが注目される．今後のSCC損 傷調查や報告作成にあたっては，環境，材料因子とと もに，機械的因子に対する関心を高める必要があるう。

\section{SCC 事例の解析}

収集された SCC 事例カードの解析に专たっては, まず図 1 に示す 6 種類の集計案についてトライアンド エラーを行い，さらに集計結果について討論を重视た。 その詳細については省略するが，最終的には解析結果 を, 第 1 章概説, 第 2 章損傷の分類, 第 3 章化学的環 境条件之 SCC 現象，第 4 章機械的性質，条件之 SCC 現象，第 5 章損傷原因々対策にま之め，全収集カード を巻末にとじこんで，設計，保全技術者のための応力 腐食割れ事例の収集と解析として出版に至ったもので

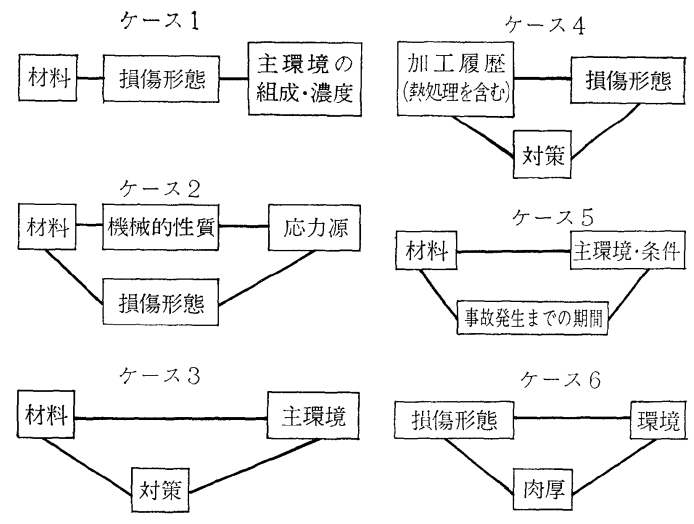

図 1 応力腐食割れに関する諸要因・要素の関連 ある。

$$
4 \text { あとがき }
$$

SCC 事例の収集と解析については一段落したが, SCC 以外の腐食損傷事例の調查 (高温腐食, 水素侵 害, 寸き腐食など), 文献以外の現象事例（未公表） の収集, 腐食損傷の起っていない事例の収集, 事例収 集活動のあり万などは今後の課題として残されている.

\section{TG「腐食事例」}

日根文男 (名工大), 駒井謙治郎 (京大工), 山崎正 八郎 (山崎精機), 大久保勝夫 (住友化学), 小若正倫, 工藤赴夫 (住友金属), 栄幸雄, 原田良夫 (三菱重工), 森稔, 寺田誠二 (川崎重工)

\section{参 考 文 献}

1）応力腐食割㣗事例の収集之解析，TG「腐食事例」(1978） 日本材料学会腐食防食部門委員会発行.

2）腐食表示委員会終了報告，材料，18，453（1969）. 


\section{委員会報告}

\section{材料の適用限界と寿命予測 ${ }^{*}$}

腐食防食部門委員会

腐食防食部門委員会は昭和52年度の例会に打いて 「材料の適用限界と寿命予測」を多方面から考察し， 第13回腐食防食㮣談会（昭和53年 2 月 28 日, 3 月 1 日, 大阪科学技術センター）でこの主題に関する総合的な 討論を展開した，との成果を踏变光て昭和53年度の例 会の主題を「適正材料選定の模索」とし，それぞれの 専門的立場から討論した。 この報告は専門別担当主查 による総括である.

\section{1 金属材料部門}

（主查 小若正倫）

第13回腐食防食懇談会の主題は「材料の適用限界々 寿命予測の可能性」であった。この主題の重要性は, 構造不況に直面している産業界に括いて, 強く認識さ れているものであり，時宜を得た取り上げ方であった。 しかし問題を討論するにつれて現段階では非常に多く の困難があり，今後旮のよらな見方での研究が行われ ることを期待して将来に問題を託した形となった。

金属材料に関しては次のような点が議論された.す なわち実験室的実験により材料の適用限界を明らかに することは，全面腐食的現象汇関する限り（たとえば 高温酸化, 酸, アルカリ溶液による腐食など）かなり 可能性があるように思われる点では意見が一致した.

したがって材料の使用条件が明らかであれば，寿命を かなりの精度で予測することができる，乙かし使用中 に条件の変動があれば，当然その予測がくずれること は言をまたない。

局部腐食に関する場合（たとえば，孔食，すきま腐 食, 応力腐食割れなど）は適用限界, 寿命予測は非常 に困難であり，湾とんど不可能に近い，その大きな理 由の一つは材料と環境の関係が時間とともに変化する ことである。すなわち腐食の伝ぱ過程において，すき ま内, 孔食内や応力腐食割孔内部の環境条件は時間と ともに変化し, $\mathrm{pH}$ の低下, $\mathrm{Cl}^{-}$の濃縮, 溶存酸素の 消耗などにより腐食性が変化する.

従来は材料の実験室的試験の初期段階においては， 先ず Yes かNoかのデータを取っていた．乙かし寿 命予測を行うためには, さらに定量的なデータが必要 となる。たと兊ば, 破壊力学的手法により割れ進行速 度を求めることが試みられているが, 環境条件の変化

* 原稿受理 昭和54年 4 月 10 日
をどのように取扱うか充分吟味しなければならない。 また腐食の評価に統計的処理を用いることが試みられ ているが，今後さらに発展することが望まれる.

実験室的加速試験結果は, 実環境のデータとの対応 に難点があり，今後実環境に対応した実験室的長期試 験を行いデータを蓄積することが唯一の寿命予測を可 能にする途であろう. 非常に地味な仕事であるが,こ の上うな努力を希望する。

たと党ば材料の耐孔食性を評価する場合, スイープ 法で孔食電位を測定することは一つの方法ではあるが， 真の値を知ることは，その環境でそれぞれの電位に長 時間保持し孔食の発生を調査し, その限界電位を求め ることにより可能である. 非常に時間のかかる仕事で あるが, このよらなデータの蓄積は防食工学の進歩に 貢献するであらう。

第87回例会（昭和53年 9 月26日）では年間主題「適 正材料選定の模索」に関し，金属材料部門として四つ の講演と討論が行われた. 先ずステンレス鋼について は, 多くの実験室試験結果が報告されたが実環境との 対応に久け，材料選定の困難さが述べられた，次いで， ニッケルおよびニッケル合金の材料特性が詳細に報告 され，材料選定上の注意が喚起された。 また炭素鋼， 低合金鋼の応力腐食割れに関し環境別に報告され，材 料選定のための金属因子の影響について詳述された。 最後に耐食銅合金の種類とその使用環境について報告 され，材料選定のための参考データが提供された.

以上のように実験室試験結果から適正材料の選定を 行らことがいかに困難であるかが明らかになるととも に，そのためにはその上らな見方でのデータの蓄積が 必要であり, 今後の課題であるとのコンセンサスが得 られた。

\section{2 非金属材料部門}

(主查 奥田 聡)

第85回例会を担当した. 高分子材料をライニングす る場合, その接着性が最重要課題となる. そのため高 分子の界面現象の理論拉よび幾つかの実例について考 察した.

防食塗装の場合にもこの接着性が重要で, それを要 約すると次のと和りである.

(1) 塗膜の接着強度評価は塗膜の適用目的に応じて 試験法を選択し, それに応じた接着強度の向上策を考 
えるべきであって，いずれの場合もWBL の除去が最 も重要である.

（2）ここで紹介したプルオフ法やトルクレンチ法な ぞ，一般に行われている接着破壊に上る接着力測定值 の比較には寸法効果のあることを考慮しなければなら ない。

（3）防食を主たる目的とした塗膜について特に水中， あるいは高湿度ふん囲気中における接着力低下のない ことが重要である.

（4）特に部分的な塗膜はく離状態に括ける防食性能 テストに対しては叙膜の水中接着力がカソードに打け るアルカリ性に耐えて低下しないことが必要であり， これによって全面腐食を防ぐ意味で良好となるが，こ の結果塗膜はく離部分の孔食はさけられない。したが って, このような条件でも被塗物強度保持の面から完 全な防食を指向するならば，合せてカソード防食法を 併用しなければ危険なことになる。

防食ライニング用の各種強化材が開発され，使用さ れている.ここではガラスフレーク（GF）について考 察した. GF 自体の特性もさることながら，母材の前 処理, トップコート, 養生など施工技術が製品の性能 を決めるのに重要なことを確認した。

樹脂ライニングの接着と耐久性関する実験室和よ び現地実績の結果を要約すれば

（1）せん断接着力試験で，マトリックス樹脂の最高 使用温度でも，鉄面との界面はく離を起さず凝集破壊 を示すこと。

（2）実用的ライニング構成でサーマルショックを与 えてもはく離しないこと。

（3）耐水性が高いこと.

（4）有機材中には水分の浸透が顕著であり，従来樹 脂の耐薬品性評価のため高濃度の酸やアルカリ中での データが取られていたが，今後はそれらに加えて希薄 水溶液を逆に高濃度水々言った見方でとら光, 皮膜一 母材, 樹脂一強化材の界面に与兄る影響も考兄るべき である.

（5）ガラスなど強化材の表面処理は実際にどら行わ れているのか，メーカーからの説明が不足である.

（6）現場で実際に行われている下地処理について未 だ不分明な点が多く，裏付けデータを充実させるとと もに実際上の基準と許容限界をもっと明確にする必要 がある.

（7）樹脂ライニングのはく離や割れについて，ぞう いう物性が，ぞういうメカニズムで，ぞの程度影響し ているのかを見極め，必要なデータをとることができ るようになれば，材料選定と寿命予測の上に大いに有 効であると思われる。

結論として構造用材料としてのプラスチックの耐食
限界の推定と寿命予測はむずかしい問題であるが，大 略以下の各項が必要之考光られる。

（1）静的浸せさによる耐薬品性評価

（2）動的条件下の耐薬品性評価

(3) 破壊事故防止と安全管理

これらについては幾つかの文献が発表されているの で参照されたい。

\section{3 防食設計防食管理部門}

（主查 山本昇三）

当部門では, 装置産業の立場からプラントの健全性 を確保し, その構造物の要求性能を満足して稼動率を 高め, 信頼性を向上させるとともに故障や事故の事前 防止対策を確立して, 客観的汇納得しうるような技術 基準と，法規制によって安全性を確保させるため，52 年度から53年度にわたって他部門の協力のもとに材料 の適用限界之寿命予測の可能性を討議しつつ, 互いに 当面している問題の解決に努力してきた.（例会資料 No. 83 および 89 参照)

\section{$3 \cdot 1$ 寿命予測}

プラント, 構造物の寿命予測は, 腐食, 強度, NDI 技術の三位一体の進歩が必要であり, 現時点ではいず れる開発途上にあり，直ちに精度の高い寿命を予測し らる段階に至っていない，しかし，寿命予測へのアプ ローチの方向は滦ぼ固まりつつあり，技術開発の舵も 次第にその方向にとられつつある。

ボイラ，ガスタービン，化学反応装置など高温下で のプラント構造部材の余寿命推定についての考方方を 整理すると, 余寿命推定は, 現在までの損傷蓄積率, 残存強度扣よび今後の運転パターンから行われる. 現 在までの損傷蓄積率は, 過去の運転履歴から温度, 応 力, ひずみレベルの分布之解析, 使用時間あるいは回 数の運転パターンの把握, 系統内の污れ量の把握とそ の影響度, 材質劣化量とその進行過程の調查解析から 得られる. 残存強度は, 強度試験および破壊力学的手 法によるき裂の伝ぱ成長速度の推定によって得られる. 余寿命は,このよらな調查解析の結果を総合して現時 点までの材料強度, 損傷劣化度を推定し, さらに今後 の使用期間に対する劣化成長の度合を予測し, これに 使用材料の材料データをインプットすることにより評 価し得る.そのアプローチとして, まず部材の劣化損 傷形態とその要因分析が必要である.その一手段とし て超音波探傷法 (Ultrasonic Test, UT), 電磁誘導試 験 (Eddy Current Test, ECT), アュースティック・ エミッション計測 (Acoustic Emission, AE) などの 適用による材料欠陥, 組織変化, 損傷和よび劣化な ぞの検出のための 非破壞検查技術 (Non-Destruction Inspection, NDI) を開発する必要がある.

上述のように余寿命推定には, き裂成長速度の評価, 
欠陥成長率, 強度低下率之残存強度, 減肉速度および 孔食進行速度などの諸因子から評価し得るが，この定 量的予測にはこれらの諸因子の評価精度の向上が必要 であり，現在の技術ではな拉不明の点も多いが，次第 にデータの蓄積と解析手法が向上しつつあるといえよ う.

\section{$3 \cdot 2$ 材料の適用限界}

全面腐食進行の様式は，(i)時間とともに腐食速度緩 慢化, (ii) 腐食速度一定, (iii)初期速度小の三つに分類で さる. Planned interval tests はこの傾向を知る一手 法であり, 腐食進行速度を予測できる実験室的試験で ある.また, Fontanaは, パイロットプラントテスト での必要最低試験時間の目安として $2000 \mathrm{hr} / \mathrm{mpy}$ を 提唱し，これはASTM G4-68 でも採用されている. 実際の腐食環境に括汿る材料の適用限界特よび寿命予 測は, 腐食媒の種類を決めることから始まり，その濃 度や使用温度などの腐食因子を正確に把握されている 必要がある. しかしながら設計の立場から考えると， 主として原料や最終製品については, その収支を詳し く検討することができるが, 中間体, 触媒, 反応助剤, 西るいはどの工程においても付随する共存不純物につ いては正確に把握しにくい，たとえば，石油精製プラ ント, 湿式りん酸プラントなどの適用材料の腐食問題 は, 共存不純物に起因することが多い. 原油の常圧 蒸留装置は古くから腐食問題に悩まされているもので あるが，その塔頂部で炭素鋼の腐食度は $4 \sim 5 \mathrm{~mm} / \mathrm{y}$ の激しい環境である.この腐食に関与するものとして 現在では原油中の硫化物や塩化物が分解してできた $\mathrm{H}_{2} \mathrm{~S}, \mathrm{HCl}$ などであることが知られている。この場合， 炭素鋼の腐食度の判定は次式で与兄られる $K$ 值をパラ メータとして示される.

$$
K=\text { 原油中のい抢う量 }(\%) / \text { 塔頂温度 }\left({ }^{\circ} \mathrm{C}\right)
$$

湿式りん酸プラントは，りん鉱石を硫酸で抽出し， 得られた稀りん酸を濃縮して所定濃度のりん酸を得る 方法であるが, 安価に製造でさる反面, 得られるりん 酸は不純であり, また高濃度への濃縮は共存不純物が 影響して腐食性が高く適正材料の選定に苦慮する難点 がある.りん鉱石からのりん酸抽出では主反応の他に， りん鉱石に含まれる不純物の関与する副反応る起る.

湿式りん酸には， $\mathrm{F}^{-}, \mathrm{SO}_{4}{ }^{2-}, \mathrm{Cl}^{-}$などの腐食を加 速する成分が共存する一方, $\mathrm{Si}^{4+}, \mathrm{Fe}^{3+}, \mathrm{Al}^{3+}, \mathrm{Mg}^{2+}$ などの腐食抑制成分も存在する。 また，副生する石こ らスラリーによるエロージョンも装置材料の寿命に影 響し, SUS 316 や 20 合金ステンレス鋼では石こう 沈積部で腐食が加速される. このょうに湿式りん酸環 境ではわずかの環境条件の変化によって腐食性が激し く変化するため, これに適用されている金属材料は SUS 316, SUS 317, 20合金, HV-9 (ベルギ規格),
二相ステンレス鋼，イリウム98，ハステロイなど多種 類にわたっている.このことは, 共存不純物の影響を 受けやすい湿式りん酸用途では主環境にの及目を向け た短絡的思考では適材選定は成功しない，換言すれば， 材料の適用限界および寿命予測は, 腐食媒の種類, 濃 度などの環境条件を正確に把握し，その条件を再現し た環境で試験することによって可能となる.

\section{$3 \cdot 3$ むすび}

上述したように材料の適用限界と寿命予測は, 全面 腐食の場合には微量の共存不純物も含めた腐食環境条 件を正確に把握し，その諸条件を実験室的試験で再現 することによってある程度可能である. 局部腐食に対 しては, 現時点で未解明の部分が多いが，やがて解析 技術の進歩とデータ蓄積とにより次第に確度の高い技 術として実用されていくことが期待される．との寿命 予測の手段としては実機の非破壊的監視技術が重要で あり, プラント稼動時の異常検出技術の研究は機器保 全, 欠陥の早期発見と対策樹立上極めて重要な分野と して着目されている.

\section{4 事故調查対策部門}

\section{(主查 森 稔)}

当部門が担当した例会，第73回（昭和50年11月）, 第 78 回（昭和51年11月）㐨よび第 82 回（昭和52年 9 月) では, 各種熱交換器類（クーラ,コンデンサ, ヒ ーティングなどのチューブ，スパイラル熱交換器な ぞ), 輸送管類 (海水導入管, 水道拈よびガスの埋設 管など), 化学装置類 (アンモニア・ソーダ・プラン ト，オレフィン反応装置，クラフト・パルプ反応装置， 排煙脱硫装置など), 回転機器類 (ブロア, ディーゼ ル・エンジン・シリンダ・カバーなど）飞関する腐食 事例が紹介された（例会資料参照）.

寿命予測手法にとって最も確かな情報は, 実環境で 使用されている各種材料の寿命である. 上記 3 回の例 会では, 各種製品抢よび材料の実環境に㧍ける腐食状 況を, 損傷に至る時間と形態, 腐食速度, 腐食率とい ら数值で発表された例が比較的多いので, 使用材料ご とに使用環境条件を付記しながら以下に紹介する.

\section{$4 \cdot 1$ 熱交換器}

SUS 304 チューブ（直径 $30 \sim 60 \mathrm{~mm}$, 厚み 2〜3 $\mathrm{mm}$ ) で腐食が発生したのはいずれもシェル側であり， 冷却水温度も常温 $40^{\circ} \mathrm{C}$ 範囲で 3 例とも似かよった 環境条件であるが, $\mathrm{Cl}^{-}$の存在 $(30 \sim 100 \mathrm{ppm})$ や濃 縮の可能性があると寿命は短くなる.

SS 41 (板厚 $3 \mathrm{~mm}$ ) のスパイラル状の伝熱板の海 水中（流速 $1 \mathrm{~m} /$ 秒以下, 温度 $20 \sim 35^{\circ} \mathrm{C}$ ) での 腐食率 は $0.2 \mathrm{mpy}$ であった.

油槽船の荷油倉ヒーティング・チューブ BsFT4 の 応力腐食割れ事例がある. 原油の粘度をさげるために 
$8 \mathrm{~kg} / \mathrm{cm}^{2} \mathrm{G}\left(\simeq 170^{\circ} \mathrm{C}\right)$ スチームを通している. 破損箇 所は，デッキ裏曲げ加工部に限られており，2.5 年で クラックを生じている.

\section{$4 \cdot 2$ 輸送管}

本例は油槽船の荷油倉内への海水バラスト導入・排 出管で, 通常 SS 41 の電縫溶接により作られている. 使用条件は常温である.

腐食率は管下部平均 $0.24 \mathrm{mpy}$, 最大 $0.6 \mathrm{mpy}$, 孔 食部平均 $0.5 \mathrm{mpy}$, 最大 $0.9 \mathrm{mpy}$.

埋設管 (普通鋼) の腐食速度は，通常あ屯り大きな ものではなく，腐食性土壌の場合 $0.06 \mathrm{mpy}$ ，また全 土壤の平均值は $0.22 \mathrm{mpy}$ である. しかし土壌の不均 一や他の構造物との接触があってマクロセルを形成す ると，0.5〜2 mpy と非常に大さな腐食速度になるこ とが報告されている。

\section{$4 \cdot 3$ 化学装置}

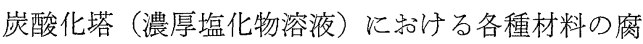
食率を比較すると鋳鉄の耐食性はそれ湴優れたもの とは言えないが，古いアンモニア法のプラントでは肉 厚を充分にとることによって，鋳鉄製で20～30年耐え ることができた。

塩安液加熱器の環境は $20 \% \mathrm{NH}_{4} \mathrm{Cl}, 10 \% \mathrm{NaCl}, \mathrm{pH}$ $\fallingdotseq 5$, 温度 $\fallingdotseq 110^{\circ} \mathrm{C}$. チタンはビーカ・テストでは良好 な結果を示したが，実環境では管板フランジ部に間げ き腐食が発生して 2 か月で漏洩した。 なた $18 \mathrm{Cr}-20$ $\mathrm{Ni}-\mathrm{Mo}-\mathrm{Cu}$ は 6 年目に貫通した。

クラフト・パルプ製造装置の液組成は, 白液の 1 例 として $\mathrm{NaOH} 96.8 \mathrm{~kg} / \mathrm{m}^{3}, \mathrm{Na}_{2} \mathrm{~S} 31.3 \mathrm{~kg} / \mathrm{m}^{3}, \mathrm{Na}_{2} \mathrm{CO}_{3}$ $27.4 \mathrm{~kg} / \mathrm{m}^{3}$. 黑液はチップ蒸解後の廃液で白液と黒

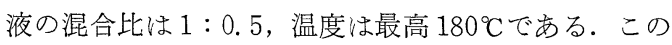
環境で白液貯槽の一般構造用圧延鋼材の腐食率は 5 $\mathrm{mm} / 3$ 年 (最大), 蒸解釜溶接部 (SM 41) では 2.0 $\mathrm{mm} /$ 年, 妾た黒液濃縮装置真空蒸発午の伝熱管 (SUS 304 電縫管) は 1 年 9 か月で漏洩した.

排煙脱硫装置の SUS 304 金網（吸収塔内）は数か 月孔食破壊した。

処理前排煙の代表的な組成は $7 \% \mathrm{CO}_{2} ， 12 \% \mathrm{O}_{2} ， 1 \%$ $\mathrm{CO}, 80 \% \mathrm{~N}_{2}, 400 \sim 1000 \mathrm{ppm} \mathrm{SO}, 120 \mathrm{~g} / \mathrm{Nm}^{3} \mathrm{H}_{2} \mathrm{O}$, 吸収液の組成は $\left(\mathrm{NH}_{4}\right)_{2} \mathrm{SO}_{4}, \mathrm{NH}_{4} \mathrm{SO}_{3},\left(\mathrm{NH}_{4}\right)_{2} \mathrm{SO}_{3}$, $\left(\mathrm{NH}_{4}\right)_{2} \mathrm{~S}_{2} \mathrm{O}_{3}$ を合計 $35 \%$ 含み, $50 \sim 55^{\circ} \mathrm{C}, \mathrm{pH}=6$, そ れにある程度の $\mathrm{Cl}^{-}$を含む。

\section{$4 \cdot 4$ 回転機器}

シリンダー・カバー (Cr-Mo 鋼, カス圧の繰返し 1.8 2. $4 \times 10^{7}$ 回） が 3000 4000 時間で清水冷却面 に割れを生じた。

コークス炉カス・ブロワ・羽根車翼 ( SNC 2, ガス 組成 $\mathrm{H}_{2}, \mathrm{CH}_{4}, \mathrm{NH}_{3}$, 温度 $35^{\circ} \mathrm{C}$, 回転数 $4700 \mathrm{rpm}$ ) のリベットと翼のつけ根に 7 年で割れが発生した。
以上にかかげた腐食損傷に関する数值は, 同じょう な環境で使用する場合の材料や製品の寿命予測を検討 する場合の参考となる. そして各種材料や製品の寿命 子測の信頼度を高めるためには, 同じょらな環境での 損傷例をできるだけ多く集めて，損傷に至るまでの経 過の解析と環境条件を詳細に把握することが必要であ る. 特に実際の環境条件は複雑で, 例えば腐食反応に 関係の深い濃度を例にとり考えてみると，腐食面の沖 合から界面にいたる濃度分布，それらの状態の経時的 な変動とその範囲扣よび積算, 腐食部に和ける濃縮の 可能性, 流動, 停滞, 伝熱の条件などがあり, これら の数值と損傷の関係を明らかにしていくことが寿命予 測の第一歩となる.

\section{5 腐食評価部門}

（主査山崎正八郎）

腐食評価には材料の適用限界を確め, 寿命予測に必 要な問題点の分析と要因の調査揖よび予測手法, 経済 性を加味した耐久性, 信頼性, 最適条件の追求が必要 となる。

寿命予測に際し, 実際の使用環境, 使用条件下で発 生する腐食の形態様式を予知し, 対策することが先決 である．均一腐食の場合は腐食速度の推定が比較的容 易であるが, 局部腐食の場合は, 発生箇所, 局部腐食 の種類, 時期および伝ぱ速度の予知が困難で, 対策と しては予知し得る最悪の場合の想定と, 偶発性に対す る考慮が必要である.

昭和 53 年度, 腐食評価部門では最も問題の多い応力 腐食割れ（SCC）に焦点を合わせ, 腐食事例より因子 の分析と整理, SCC のメカニズムに対応する腐食試 験法の調査と, 確率的評価法を追求し, 第90回部門委 員会に扣いて，SCC および腐食疲労 (CF) の損傷実 態の整理 - 解析, 金属材料の応力腐食割れ試験方法, 局部腐食の確率的評価, また第13回研究集会に沶いて， 応力腐食割れとひずみ電極, 定ひずみ速度引張応力応 力割れ試験法の背景と特徵の研究発表を行い, 活発な 意見交換がなされた.

\section{$5 \cdot 1$ SCC および CF の損傷実態の整理解析}

腐食防食部門委員会「腐食事例タスク・グループ」 で収集したカードを基にして整理，解析した結果， SCC の事例総数243例（外国文献 73, 国内文献170） 中, 比較的よく把握されていた項目は, 損傷した機器, 装置名, 損傷箇所, 事故発生までの時間, 構成材料, 主環境の組成・濃度であり, 最も重要な応力源とその 程度に関する記入の少いことがわかったが，これは害 装置に执いて SCC 発生と応力源とを直接関係づける ことのむずかしさを示したものと考兄られる。

この調査では発生した機器装置別分類と使用金属の 種類との対応を考察している. 応力源をもつ構造や使 
用状態によって応力のかかる懸念のある機器装置では, 材料の種類によって特有の割れ時間と頻度が認められ， これらは環境, 温度, 溶接の有無などに影響される。

金属の種類による割れの形態, き裂径路の分析整理が できているので，応力源を残留応力，作用応力に分け， 更に作用応力を静応力の及ではなく, 機械的振動応力 や温度変化による熱応力の繰返しが重畳することがあ ると考光た。

実験室試験によれば，重畳する繰返し応力により， 活性路溶解型繰返し SCC, 水素ぜい化 (HE) 型繰返 しSCC など, 振動が SCC を加速するメカニズムが わかったＳＣ～に関連する材料の寿命予測と適用限 界を知るには静的 SCC ばかりでなく, 繰返し応力腐 食割れ， SCC とCF の組合せおよび CF についての 考慮が必要である。さらに板厚の影響を無視し得ない ので, 実装置に乱ける機械的応力扔よび熱応力, 振動 に上る応力源汇関するデータの積み重䄈が重要である.

\section{$5 \cdot 2$ SCC のメカニズムに対応する試験方法の 展望}

$5 \cdot 2 \cdot 1$ 研究発表から見られる材料と環境および 応力負荷方法 $1977 \sim 78$ 年に発表された 48 件の SCC 飞関する研究の内容は材料, 環境, 応力負荷方法別飞 分類することができる、材料と環境の組合せと関し， 低合金鋼, ステンレス鋼, Ni 合金, 銅合金, Al 合金, Ti 合金などが特徵ある SCC 感受性を示す試験液が選 定され，また応力負荷方法としては，定ひずみ法，定 荷重法抢よび定ひず文速度が用いられている，定ひず み法ではU曲げ, ダブルU曲げやCリング法, 定荷重 法では単軸引張りや管状試験片内俚法などが用いられ， また切欠き十疲労クラック導入による破壞力学的研究 やねじり応力 (Mode III) 下の SCC 試験により水素 ぜい化と活性路腐食を分離しようとする試みがある。

$5 \cdot 2 \cdot 2 \mathrm{SCC}$ 試験法における環境の役割と電気化 学的解析 Staehle の提唱した金属材料の陽分極曲線 飞扝汗る領域 1 (活性態域), 領域 2 (活性/不動態遷 移域）および領域 3 (過不動態域) の表面皮膜を熱力 学的立場とともに, 溶解反応と再不働化との競争反応 としての見地から考察しまた実環境下での自然電位 を知るとともに実環境液より強い腐食性の試験液を使 用して試験片の自然電位と陽分極曲線を測定する.こ れらのデータから実環境での SCC に強い材料選定を
迅速かつ適正に実施しょうとするようになってきた。

$5 \cdot 2 \cdot 3$ 応力負荷方法と SCC メカニズムとの 対 応 SCC のメカニズムを大別すると，(1)メカノケミ カル説（割れ先端の活性化），(2)皮膜破壞（すべりス テップ溶解), (3)ぜい化皮膜の連続的破壊説, (4)応力 吸着説（表面活性物吸着による表面エネルギ低下）な ぞがあり，(4)を除いていずれも何らかの形で表面皮膜 の破壊と関連し，重要なのは応力そのものではなく，

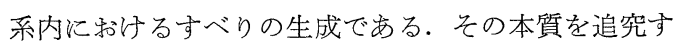
るものとして定ひずみ速度法が研究され，いろいろと 示唆に富も試験結果が得られるよらになったが，(1)定 ひずみ法や定荷重法で得られる TTF のよらな明確な 感受性評価法がない（2)伝ぱ過程のみから選定した材 料が適材かといら疑問と，ひずみ速度を小さくするこ とにより，実際との相関性は向上するが迅速試験の意 義を失うなどの問題点が解決されていない. S-S 曲線 からの解析や SCC 破面率 $I_{\mathrm{SCC}}$ による評価法により， SCC のメカニズムの追究やスクリニングテストへの 適用の努力がなされている.

な拉，定ひずみ速度法によるすべりメカニズムの再 現と,ひずみ電極法による(1)ひずみ量から表面積変化 量の算出, (2) S-S 曲線との対応に上る塑性変形挙動 とアノード活性との関係づけなど, SCC のメカニズ ムに対応する試験法の研究が各方面で活発化している.

$5 \cdot 2 \cdot 4$ 局部腐食の確率的評価 局部腐食の速度 は本質的にランダムであり，確率的性質をもっている ことは, 孔食電位, すき腐食電位, SCC 寿命など の分布が確率的分布により整理されることにより明ら かである、すなわち，正規分布（孔食電位，すきま腐 食電位, 孔食数分布之電位, すき省食深さ), 対数正 規分布 (SCC 寿命, すき腐食開始時間), ポアソン 分布 (孔食数の二次元分布), 指数分布 (孔食発生誘 導時間, $\mathrm{HE}$ 破断寿命, ピット径の分布), 極值分布 (孔食最大深さ)，ワイブル分布 (SCC 寿命) などの 関係が認められ，寿命予測には実験室試験にお和る寿 命分布と実際環境における寿命分布の比較が重要とな ってきている.このよらな関係の追究はワイブル分布 の適用が期待されて和り, その的の值の傾向から, メ カニズムの分析や初期不良型, 偶発型, 摩耗型に整理 したうえで比較することが必要で, そのためのデータ の蓄積が先決問題である. 